\title{
GENOTYPING OF HEPATITIS B VIRUS IN A COHORT OF PATIENTS EVALUATED IN A HOSPITAL OF PORTO ALEGRE, SOUTH OF BRAZIL
}

\author{
Carlos Eduardo BECKER'1, Angelo Alves de MATTOS ${ }^{1}$, Maurício Reis BOGO², \\ Fernanda BRANCO ${ }^{1}$, Roberta SITNIK ${ }^{3}$ and Nelson Alexandre KRETZMANN ${ }^{1}$
}

\begin{abstract}
Context - In recent years the hepatitis B virus (HBV) genotyping has been considered a relevant factor in the natural history of the disease. Objective - To determine hepatitis B virus genotypes and its epidemiological and clinical implications, in a cohort of patients in a hospital in Porto Alegre, South of Brazil. Methods - Sixty seven patients with HBV chronic infection markers who were being treated at "Complexo Hospitalar Santa Casa", in Porto Alegre, RS, Brazil, were evaluated. Demographic and epidemiological data were collected from these group of patients by following a standard protocol and ALT and HBeAg were determined. The genotypes and subtypes were determined by in-house PCR and, finally, the samples were sequenced. The level of significance used was $5 \%$. Results - The qualitative analysis for HBV-DNA by PCR was positive in $79.1 \%$ of the samples (53/67). The genotype was determined in all positive VHB-DNA samples and the genotypes A (34\%), D (60.4\%) and F (5.4\%) as well as the subtypes adw, ayw and adw4 were found. No significant correlation was found between the hepatitis B virus genotypes and demographic variables considered as risk factors for hepatitis B virus infection. There was also no correlation between the genotypes and the serological and laboratory variables related to liver disease. Conclusion - We concluded that the most prevalent genotype found was D. However, further studies are needed to allow us to evaluate the implications of genetic variability in the clinical evolution of HBV carriers.

HEADINGS - Hepatitis B virus, genetics. Hepatitis B, virology. Genotype.
\end{abstract}

\section{INTRODUCTION}

Epidemiological studies show that hepatitis B is responsible for 2 million deaths per year in the whole world ${ }^{(17)}$, and this disease is the $9^{\text {th }}$ cause of death in the world ${ }^{(6)}$. In Brazil, the Ministry of Health estimates that at least, $15 \%$ of the population has already been contaminated by the hepatitis B virus (HBV), and the chronic cases correspond to about 5\%-10\% of the Brazilian population, with the South region considered as a low endemicity area ${ }^{(3)}$. Historically, the diagnosis of HBV hepatitis focuses on serological markers, however molecular technology has made great advances, and now it is possible to evaluate the DNA of HBV qualitatively and quantitatively, and also to identify the genotypes and their subtypes ${ }^{(7)}$.

Previous analyses of the genome revealed eight HBV genotypes (A-H), with a distinct geographical distribution worldwide ${ }^{(16,28)}$. Besides the genotypes, there are four main serological subtypes of HBV (adw, ayw, adr and ayr) or nine secondary subtypes: adw (adw2, adw4); ayw (ayw1, ayw2, ayw3, ayw4); $\operatorname{adr}\left(\right.$ adrq+, adrq -) and ayr ${ }^{(14)}$.
Genotypes A and D are more prevalent in Brazil, Europe, North America, India and Africa; genotypes $\mathrm{B}$ and $\mathrm{C}$ are more frequently found in Southeast Asia, China and Japan; genotype $\mathrm{E}$ is limited to Africa; genotype $\mathrm{F}$ is found among the native population of South America and Central America; genotype G was described in France, United States and Mexico, and genotype $\mathrm{H}$ was found in Central America ${ }^{(2,14,15,16)}$.

A few studies demonstrated that a wide spectrum of clinical manifestations of liver disease caused by $\mathrm{HBV}^{(13,14,16,18)}$, as well as the response to the antiviral treatment ${ }^{(12,33)}$, could be related to the virus genotypes. Therefore, the genotyping of HBV has been subject of much interest in providing care to these patients ${ }^{(21)}$.

Despite of the epidemiological importance and clinical knowledge of HBV genotypes, it is still not well known the genotypic distribution of this infection in Latin America ${ }^{(1,31,32)}$. In Brazil few studies showing the genotypes prevalence and HBV subtypes have been published so far ${ }^{(4,9,10,20,23,26,32)}$. In Rio Grande do Sul, until now, no scientific center had implemented the technique to determine the hepatitis B virus' genotyping and subtyping. Therefore, we have proposed to implement

'Pos-Graduate Program in Hepatology, Universidade Federal de Ciências da Saúde de Porto Alegre, Porto Alegre, RS, Brazil; ${ }^{2}$ Genotype and Molecular Biology Center, Pontifícia Universidade Católica, Rio Grande do Sul, Porto Alegre, RS, Brazil; ${ }^{3}$ Laboratory of Special Techniques, Hospital Israelita Albert Einstein, São Paulo, SP, Brazil. Correspondence; Dr. Carlos Eduardo Becker - Rua Felippe Nery 253/303 - 90440-150 - Porto Alegre, RS, Brazil. Email: cacaubecker@terra.com.br 
it in a cohort of patients assessed in a hospital to evaluate its prevalence and its correlation with the demographic data, risk factors and serological status of the liver disease.

\section{METHODS}

The 67 consecutive patients with chronic HBV markers infection were evaluated, with 52 of them being followed at the gastroenterology clinic and 15 at the hemodialysis unit at "Complexo Hospitalar Santa Casa", Porto Alegre, RS, Brazil, from February 2005 to September 2006.

The inclusion criteria were: patients with serum positive for $\mathrm{HBsAg}$ for longer than 6 months, independently of serum levels of aminotransferases.

The exclusion criteria were: patients with positive anti$\mathrm{HCV}$, positive anti-HIV, and alcohol intake greater than $40 \mathrm{~g} /$ day, use of potentially hepatotoxic medications and patients who did not sign the informed consent.

A pre-established protocol with demographic and epidemiological data of each patient was completed.

After blood collection, plasma was separated and the samples were stored in a freezer at $-20^{\circ} \mathrm{C}$ for further analysis. $\mathrm{HBsAg}$ and $\mathrm{HBeAg}$ were analyzed by electrochemoluminescence (Elecsys 2010 - Roche) and kinetic colorimetry (Advia 1650 - Bayer) was used to measure ALT.

\section{Polymerase chain reactions (PCR)}

HBV DNA was detected by PCR using specific primers covering the core $(\mathrm{C})$ and surface (S) genes of the HBV genome. In all HBsAg positive samples, extraction and amplification of HBV-DNA were carried out by nested PCR. Samples with positive PCR result were further submitted to another PCR reaction covering a fragment of 417 base pairs of the $S$ gene as developed by SITNIK et al. ${ }^{(25)}$.

\section{Sequencing reactions}

PCR products covering the $S$ gene were submitted to cycle sequencing reactions, using the second round primers with dideoxinucleotides (ddNTPs) labelled with fluorescent markers (ABI PrismR BigDyeTM Terminator Cycle Sequencing Ready Reaction Kit - Applied Biosystems, Foster City, CA,USA).

\section{Genotyping}

Genotype analysis was carried out through the comparison of obtained sequences against different HBV genotypes sequences, from the Genbank. For this purpose, EditSeq and Megalign softwares from the DNAstar package (Lasergene Inc., USA) were used. The protocol was approved by the Ethics in Research Committee of the institution.

A descriptive analysis was performed for statistical analysis, using means and standard deviation for continuous variables, and relative absolute frequency for categorical variables. The $t$ Student test, analysis of variance and chi-square test were used to compare the groups. For all comparisons a 5\% level of significance was considered. A statistic package was used (SPSS version 13.0 for Windows).

\section{RESULTS}

The qualitative analysis for HBV-DNA was positive in $79.1 \%$ of the samples (53/67). Among the 53 patients selected, genotypes A, D and F were detected, and the most frequent was type $\mathrm{D}$, which was found in $60.4 \%$ of the population (32 patients) followed by genotype A, 18 cases (34.0\%). Genotype $\mathrm{F}$ was found in only 3 samples $(5.4 \%)$. The isolated subtypes were: adw in the patients with genotype A, ayw in patients with genotype $\mathrm{D}$ and adw4 in patients with genotype $\mathrm{F}$.

The age of the patients whose samples were genotyped varied from 23 to 79 years $(46.73 \pm 13.05)$. There was no statistically significant difference between the mean ages of the patients with different HBV genotypes $(P=0.436)$. Regarding gender, $75.5 \%$ were male $(\mathrm{n}=40)$ and $24.5 \%$ female $(\mathrm{n}=13)$. There was no statistically significant difference in the distribution of HBV genotypes concerning the gender $(P=0.584)$. Most of the patients whose virus was genotyped were Caucasian $(92.5 \%)$.

Twenty-eight $(53.8 \%)$ of the patients attending the outpatient clinic were infected by genotype $\mathrm{D}$, followed by 11 patients $(21.2 \%)$ with genotype A and 3 patients (5.8\%) with genotype $\mathrm{F}$. As to patients on hemodialysis, the most frequent genotype found was genotype $\mathrm{A}$ in 7 patients (46.6\%) followed by genotype $\mathrm{D}$ with 4 patients $(26.7 \%)$.

Regarding the identified risk factors, $23.9 \%$ (16/67) of the patients caught the virus through sexual relationships, $4.5 \%$ (3/67) were intravenous drug users; three $(4.5 \%)$ had a history of blood transfusions; three $(4.5 \%)$ of vertical transmission and two $(2.9 \%)$ of needlestick accidents. Hemodialysis was detected as a risk factor in 26/67 (38.8\%) of the patients studied. The risk factor was not identified in 20.9\% (14/67) of the patients; all of them mentioned having undergone surgery. The HBV genotypes distribution in relation to the risk factor, as seen in Table 1, cannot be statistically evaluated based on the stratification of the variables and the small number of patients in each group.

Regarding the 25 patients with positive $\mathrm{HBeAg}$, in almost all of them the HBV genotype was A $(36.0 \%)$ or D (48.0\%). In patients with negative $\mathrm{HBeAg}$ and elevated ALT (probable pre-core mutants), the percentage with genotype A and D was $29.6 \%$ and $51.9 \%$ respectively. In contrast, patients with negative $\mathrm{HBeAg}$ and normal ALT (probably inactive carriers) the genotype of $\mathrm{HBV}$ in $6.7 \%$ was $\mathrm{A}$ and in $40.0 \% \mathrm{D}$. There was no statistically significant difference in HBV genotype distribution when the serological and laboratory pattern of the patients' liver disease was evaluated $(P=0.313)$. The data can be seen in Table 2 .

\section{DISCUSSION}

According to data from the World Health Organization, approximately $30 \%$ of the world population has already been infected by HBV, and about 350-400 million individuals are chronic carriers of the disease. The prevalence of HBV infection among us is low, about $0.4 \%(26,32)$. 
TABLE 1. Distribution of the HBV genotypes in relation to the risk factor

\begin{tabular}{|c|c|c|c|c|c|}
\hline & Genotype A & Genotype D & Genotype F & Non Detectable & Total \\
\hline \multirow[t]{2}{*}{ Sexual } & 6 & 6 & 0 & 4 & 16 \\
\hline & $(37.5 \%)$ & $(37.5 \%)$ & - & $(25.0 \%)$ & $(100 \%)$ \\
\hline \multirow[t]{2}{*}{ IV Drugs } & 0 & 2 & 1 & 0 & 3 \\
\hline & - & $(66.7 \%)$ & $(33.3 \%)$ & - & $(100 \%)$ \\
\hline \multirow[t]{2}{*}{ Transfusion } & 3 & 0 & 0 & 0 & 3 \\
\hline & $(100.0 \%)$ & - & - & - & $(100 \%)$ \\
\hline \multirow[t]{2}{*}{ Vertical transmission } & 1 & 2 & 0 & 0 & 3 \\
\hline & $(33.3 \%)$ & $(66.7 \%)$ & - & - & $(100 \%)$ \\
\hline \multirow[t]{2}{*}{ Puncture (needlestick) accident } & 0 & 1 & 1 & 0 & 2 \\
\hline & - & $(50.0 \%)$ & $(50,0 \%)$ & - & $(100 \%)$ \\
\hline \multirow[t]{2}{*}{ Dialysis } & 7 & 11 & 0 & 8 & 26 \\
\hline & $(26.9 \%)$ & $(42.3 \%)$ & - & $(30.8 \%)$ & $(100 \%)$ \\
\hline \multirow[t]{2}{*}{ Non identified } & 1 & 10 & 1 & 2 & 14 \\
\hline & $(7.1 \%)$ & $(71.5 \%)$ & $(7.1 \%)$ & $(14.3 \%)$ & $(100 \%)$ \\
\hline
\end{tabular}

TABLE 2. Distribution of HBV genotypes in relation to the serologic and laboratory standard of liver disease

\begin{tabular}{|c|c|c|c|c|c|}
\hline & Genotype A & Genotype D & Genotype F & Non detectable & Total \\
\hline $\mathrm{HBeAg}+\mathrm{ALT} \uparrow$ & $4(22.2 \%)$ & $10(55.6 \%)$ & $1(5.6 \%)$ & $3(16.6 \%)$ & $18(100 \%)$ \\
\hline HBeAg + ALT normal & $5(71.4 \%)$ & $2(28.6 \%)$ & $0(0 \%)$ & $0(0 \%)$ & $7(100 \%)$ \\
\hline $\mathrm{HBeAg}+($ total $)$ & $9(36.0 \%)$ & $12(48.0 \%)$ & $1(4.0 \%)$ & $3(12.0 \%)$ & $25(100 \%)$ \\
\hline $\mathrm{HBeAg}-\mathrm{ALT} \uparrow$ & $8(29.6 \%)$ & $14(51.9 \%)$ & $2(7.4 \%)$ & $3(11.1 \%)$ & $27(100 \%)$ \\
\hline HBeAg - ALT normal & $1(6.7 \%)$ & $6(40.0 \%)$ & $0(0 \%)$ & $8(53.3 \%)$ & $15(100 \%)$ \\
\hline
\end{tabular}

$(P=0,313)$

The presence of $79.1 \%$ of positive viral DNA in our sample is in accordance with the $76 \%$ found by Carrilho et al. ${ }^{(4)}$. Chu et al. ${ }^{(8)}$, in a study carried out in the United States of America on 694 patients, also found $76 \%$ of positiveness. This scenario was similar to the one found by other authors ${ }^{30}$. ${ }^{32}$ ) whose HBV-DNA positiveness varied from $67 \%$ to $88.6 \%$ of the HBsAg positive samples.

The results found in the present study show a high prevalence of genotype D $(60.4 \%)$ followed by genotype A $(34.0 \%)$. Genotype $\mathrm{F}$ was found in only $5.4 \%$ of the genotyped population.

Genotype distribution in the Brazilian population is correlated to the origin of our ancestors. Oswaldo Cruz Institute ("IOC-Instituto Oswaldo Cruz"), which was the pioneer in establishing the genotypes of the viruses in Brazil, pointed out that about $50 \%$ of the viruses found in the country are genotype A, an African subtype, possibly related to the arrival of Africans in Brazil during the slave trade ${ }^{(32)}$. In Rio Grande do Sul, there is a prevalence of European ancestry and approximately $90 \%$ of the patients presented here were Caucasian, which could explain the lower prevalence of genotype A found in this study. The same genotypes were also found in five other studies performed in Brazil in the states of Goiás, Rio de Janeiro and Santa Catarina ${ }^{(4,9,10,20,}$ 32). In the South, composed by the states of Rio Grande do Sul, Paraná and Santa Catarina, notes the occurrence of two major genotypes (A and D), where genotype $\mathrm{D}$ appears as predominant $(84.2 \%)$ followed by genotype A (15.8\%). Genotype D has precore mutations in higher incidence, and no other genotypes were reported at this moment. This fact reinforces the hypothesis that some studies suggest as an explanation for Brazilian genomic variations, which attaches to the immigration responsibility for these differences ${ }^{(26)}$.

Another study conducted in the South region ${ }^{(4)}$ demonstrated the same frequency of HBV genotypes we found, genotype $\mathrm{D}$ being the most frequent, followed by genotype A, and less frequently, by genotype F. However, a study performed in Bahia State ${ }^{(23)}$ on individuals with a diagnosis of chronic hepatitis B demonstrated that the most frequent genotype was A, followed by genotype $\mathrm{F}$, contrasting with the result shown here. Sitnik et al. ${ }^{(26)}$ published the first study that detected genotypes $\mathrm{B}$ and $\mathrm{C}$ in Brazil in a population of more than 100 patients. However, all those infected with genotypes B or $\mathrm{C}$ were of Asian descent.

The subtypes found in the present study were ayw $(60.4 \%)$ in patients with genotype $\mathrm{D}$, adw (34\%) in patients with genotype A and adw4 (5.4\%) in patients with genotype F. Teles et al. ${ }^{(32)}$, studying a population of patients on hemodialysis in the city of Goiânia, demonstrated a different frequency regarding the subtypes (adw 2 in $44 \%$ and ayw 3 in $41 \%$ of the subtyped patients). Subtypes adw 4 and ayw 2 were observed in 3\% of the population studied. Similar results were observed in 51 HBsAg-positive patients treated in the public health system of the same city, where $62.7 \%$ were subtype adw $2,23.5 \%$ ayw3, $9.8 \%$ ayw 2 and $3.9 \%$ adw4 ${ }^{(25)}$. In another Brazilian study performed with miners exposed to malaria who worked in the Amazon region, 59\% of subtype adw2, $8.1 \%$ adw 4 and adw3 and $5.4 \%$ ayw $2^{(27)}$ were found.

As to risk factors, dialysis was most prevalent (38.8\%) among the patients studied. It is known that hemodialysis 
centers are potential transmitters of HBV because of excessive reuse of material, inefficient methods for sterilizing the membranes, and failure to comply with the universal sterilization precautions. Likewise, delay in identifying $\mathrm{HBV}$-infected patients, and consequently isolating them in a specific room (yellow room) with specific equipment, favors nosocomial transmission ${ }^{(4,32)}$. Carrilho et al..$^{(4)}$ demonstrated that a patient's risk of catching HBV in hemodialysis increases 1.47 times for every month of treatment: 1.96 times if the dialysis centers reuse the filters more than 10 times and 3.42 times if the number of patients per health technician at the center is greater than five. Genotype distribution differs among the hemodialysis centers. Thus, Teles et al. ${ }^{(32)}$, studying a population of patients in the city of Goiânia, found a similar prevalence of infected patients with genotype A and with D (50\% x 46\%). However, in another study, Ferreira et al. ${ }^{(10)}$ demonstrated genotype D as the most frequent $(61.5 \%)$. This result was presented also by Carrilho et al. ${ }^{(4)}$, in a study at 22 hemodialysis centers in Santa Catarina State, where $57 \%$ of the patients on hemodialysis were also genotype D. In the study conducted here, we observed that genotype $\mathrm{D}$ is the one most frequently found in the patients on hemodialysis.

When we evaluated HBV genotypes distribution, according to the serological and laboratory standard of the disease (Table 2), we observed that genotype $\mathrm{D}$ was more prevalent in patients with a viral response replication (HBeAg reagent) and with elevated ALT. However, the study done in the city of Salvador ${ }^{(23)}$ demonstrated that from 12 cases that were in the viral replication phase, $10(83 \%)$ were infected by genotype A. In the present study, in the cases of chronic hepatitis B with non-reagent $\mathrm{HBeAg}$ and elevated ALT, suggesting the possibility of pre-core mutation, genotype $\mathrm{D}$ was the most prevalent, matching other studies from the national ${ }^{(9,26)}$ and international ${ }^{(5,11,22,24,29)}$ literature.

In the group of non-reagent $\mathrm{HBeAg}$ and normal ALT patients, in 8 cases $(53.3 \%)$ the HBV-DNA was non detectable, possibly because since the patients were "inactive VHB carriers" the viral load was below the limit of sensibility of the PCR test used. In the seven cases in which HBV-DNA was detected, six were infected by genotype $\mathrm{D}$ and the other patient by genotype A. Ribeiro et al. ${ }^{(23)}$, studying 76 chronic carriers of $\mathrm{HBV}$ in a population of the city of Salvador, where 61 patients $(80 \%)$ were inactive carriers, detected genotype $\mathrm{A}$ in 53 cases $(70 \%)$.

\section{CONCLUSION}

According to our study results, despite the success achieved in demonstrating a greater prevalence of genotypes $\mathrm{D}$ and A in the evaluated population, no statistic difference was found between the HBV genotypes and the demographic variables studied with the risk factor for $\mathrm{HBV}$ infection, and with the serological and laboratory pattern of liver disease. The genotype A showed only subtype adw, the genotype D only subtype ayw and F only the subtype adw4, which demonstrated, that patients from Southern Brazil have a distinct feature compared to the other patients in Brazil. We understand that prospective studies are necessary, with a larger number of cases, so that in future we will know the true impact of genotype determination in evaluating the evolution of the liver diseases, and in decisions regarding the therapeutic management of patients with a chronic liver disease involving HBV virus.

Becker CE, Mattos AA, Bogo MR, Branco F, Sitnik R, Kretzmann NA. Genotipagem do vírus da hepatite B em uma coorte de pacientes atendidos em um hospital de Porto Alegre, sul do Brasil. Arq Gastroenterol. 2010;47(1):13-7.

RESUMO - Contexto - Nos últimos anos a genotipagem do vírus da hepatite B (VHB) tem sido considerado fator relevante para a história natural da doença. Objetivos - Determinar os genótipos do VHB e suas implicações clínicas e epidemiológicas, em uma coorte de pacientes em um hospital de Porto Alegre, RS, sul do Brasil. Métodos - Foram avaliados 67 pacientes com marcadores de infecção crônica pelo VHB que estavam sendo tratados no Complexo Hospitalar Santa Casa de Porto Alegre, RS. Foi aplicado um protocolo com dados demográficos e epidemiológicos dos pacientes, e AgHBe e ALT foram determinadas. Os genótipos e subtipos foram determinados por PCR in-house e, finalmente, as amostras foram sequenciadas. O nível de significância utilizado foi de 5\%. Resultados - A análise qualitativa de VHB-DNA por PCR foi positiva em $79,1 \%$ das amostras (53/67). O genótipo foi determinado em todas as amostras de VHB-DNA positivo. A análise demonstrou a presença dos genótipos A (34\%), D $(60,4 \%)$ e F $(5,4 \%)$. Foram encontrados os seguintes subtipos: adW, ayw e adw4. Nenhuma correlação significativa foi encontrada entre os genótipos do VHB e as variáveis demográficas estudadas como fator de risco para infecção pelo VHB, e com os exames sorológicos e laboratoriais de doença hepática. Conclusão - O genótipo mais prevalente encontrado foi o D. No entanto, mais estudos são necessários para que se possa avaliar as implicações da variabilidade genética na evolução clínica de portadores do VHB.

DESCRITORES - Vírus da hepatite B, genética. Hepatite B, virologia. Genótipo. 


\section{REFERENCE}

1. Arauz-Ruiz P, Norder H, Visona KA, Magnius LO. Genotype F prevails in HBV infected patients of hispanic origin in Central America and may carry the precore stop mutant. J Med Virol. 1997;51:305-12.

2. Arauz-Ruiz P, Norder H, Robertson BH, Magnius LO. Genotype H: a new Amerindian genotype of hepatitis B virus revealed in Central America. J Gen Virol. 2002;83:2059-73.

3. Brasil. Ministério da Saúde. Secretaria de Vigilância em Saúde. Departamento de Vigilância Epidemiológica. Hepatites virais: o Brasil está atento. $3^{\mathrm{a}}$ ed. Brasília: Ministério da Saúde; 2008.

4. Carrilho FJ, Moraes CR, Pinho JR, Mello IM, Bertolini DA, Lemos MF, Moreira RC, Bassit LC, Cardoso RA, Ribeiro-dos-Santos G, Da Silva LC. Hepatitis B virus infection in Haemodialysis Centres from Santa Catarina State, Southern Brazil. Predictive risk factors for infection and molecular epidemiology. BMC Public Health. 2004;4:13.

5. Chan HL, Tse CH, Ng EY, Leung KS, Lee KH, Tsui SK, Sung JJ. Phylogenetic, virological, and clinical characteristics of genotype $\mathrm{C}$ hepatitis $\mathrm{B}$ virus with TCC at codon 15 of the precore region. J Clin Microbiol. 2006;44:681-7.

6. Chen CH, Lee CM, Lu SN, Changchien CS, Eng HL, Huang CM, Wang JH, Hung $\mathrm{CH}, \mathrm{Hu}$ TH. Clinical significance of hepatitis B virus (HBV) genotypes and precore and core promoter mutations affecting $\mathrm{HBV}$ e antigen expression in Taiwan. J Clin Microbiol. 2005;43:6000-6.

7. Chen CH, Lee CM, Lu SN, Changchien CS, Wang JC, Wang JH, Hung CH, Hu $\mathrm{TH}$. Comparison of sequence changes of precore and core promoter regions in $\mathrm{HBeAg}$-positive chronic hepatitis B patients with and without $\mathrm{HBeAg}$ clearance in lamivudine therapy. J Hepatol. 2006;44:76-82.

8. Chu CJ, Keeffe EB, Han SH, Perrillo RP, Min AD, Soldevila-Pico C, Carey W, Brown RS Jr, Luketic VA, Terrault N, Lok AS; U.S. HBV Epidemiology Study Group. Prevalence of HBV precore/core promoter variants in the United States. Hepatology. 2003;38:619-28.

9. De CL, Niel C, Gomes SA. Low frequency of mutations in the core promoter and precore regions of hepatitis $\mathrm{B}$ virus in anti-HBe positive Brazilian carriers. BMC Microbiol. 2001;1:10.

10. Ferreira RC, Teles SA, Dias MA, Tavares VR, Silva SA, Gomes SA, Yoshida $\mathrm{CF}$, Martins RM. Hepatitis B virus infection profile in hemodialysis patients in Central Brazil: prevalence, risk factors, and genotypes. Mem Inst Oswaldo Cruz. 2006;101:689-92.

11. Gerlich WH, Goldmann U, Muller R, Stibbe W, Wolff W. Specificity and localization of the hepatitis B virus-associated protein kinase. J Virol. 1982;42:761-6.

12. Iloeje UH, Yang HI, Su J, Jen CL, You SL, Chen CJ. Predicting cirrhosis risk based on the level of circulating hepatitis B viral load. Gastroenterology. 2006; 130:678-86

13. Janssen HL, van Zonneveld $M$, Senturk $H$, Zeuzem S, Akarca US, Cakaloglu Y, Simon C, So TM, Gerken G, de Man RA, Niesters HG, Zondervan P, Hansen B, Schalm SW; HBV 99-01 Study Group; Rotterdam Foundation for Liver Research. Pegylated interferon alfa-2b alone or in combination with lamivudine for $\mathrm{HBeAg}$-positive chronic hepatitis $\mathrm{B}$ : a randomised trial. Lancet. 2005;365:123-9.

14. Jutavijittum P, Jiviriyawat Y, Yousukh A, Kunachiwa W, Toriyama K. Genotypes of hepatitis B virus among voluntary blood donors in northern Thailand. Hepatol Res. 2006;35:263-6.

15. Kao JH, Chen PJ, Lai MY, Chen DS. Hepatitis B genotypes correlate with clinical outcomes in patients with chronic hepatitis B. Gastroenterology. 2000;118:554-9.

16. Lindh M, Andersson AS, Gusdal A. Genotypes, nt 1858 variants, and geographic origin of hepatitis B virus--large-scale analysis using a new genotyping method. J Infect Dis. 1997; 175:1285-93.

17. Lupberger J, Hildt E. Hepatitis B virus-induced oncogenesis. World J Gastroenterol. 2007; $13: 74-81$

18. Maddrey WC. Hepatitis B: an important public health issue. J Med Virol 2000;61:362-6

19. Milich DR, Jones JE, Hughes JL, Price J, Raney AK, McLachlan A. Is a function of the secreted hepatitis B e antigen to induce immunologic tolerance in utero? Proc Natl Acad Sci U S A. 1990;87:6599-603.

20. Moraes MT, Gomes SA, Niel C. Sequence analysis of pre-S/S gene of hepatitis B virus strains of genotypes A, D, and F isolated in Brazil. Arch Virol. 1996;141:176773.

21. Norder H, Courouce AM, Magnius LO. Complete genomes, phylogenetic relatedness, and structural proteins of six strains of the hepatitis B virus, four of which represent two new genotypes. Virology. 1994;198:489-503.

22. Orito E, Mizokami M, Sakugawa H, Michitaka K, Ishikawa K, Ichida T, Okanoue $\mathrm{T}$, Yotsuyanagi $\mathrm{H}$, Iino S. A case-control study for clinical and molecular biological differences between hepatitis B viruses of genotypes B and C. Japan HBV Genotype Research Group. Hepatology. 2001;33:218-23.

23. Ribeiro NR, Campos GS, Angelo AL, Braga EL, Santana N, Gomes MM, Pinho JR, De Carvalho WA, Lyra LG, Lyra AC. Distribution of hepatitis B virus genotypes among patients with chronic infection. Liver Int. 2006;26:636-42.

24. Rodriguez-Frias F, Buti M, Jardi R, Cotrina M, Viladomiu L, Esteban R, Guardia J. Hepatitis B virus infection: precore mutants and its relation to viral genotypes and core mutations. Hepatology. 1995;22:1641-7.

25. Silva CO, Azevedo MS, Soares CM, Martins RM, Ramos CH, Daher RR, Cardoso DD. Seroprevalence of hepatitis B virus infection in individuals with clinical evidence of hepatitis in Goiania, Goias. Detection of viral DNA and determination of subtypes. Rev Inst Med Trop Sao Paulo. 2002;44:331-4.

26. Sitnik R, Pinho JR, Bertolini DA, Bernardini AP, da Silva LC, Carrilho FJ. Hepatitis B virus genotypes and precore and core mutants in Brazilian patients J Clin Microbiol. 2004;42:2455-60.

27. Souto FJ, Fontes CJ, Gaspar AM. Prevalence of hepatitis B and C virus markers among malaria-exposed gold miners in Brazilian Amazon. Mem Inst Oswaldo Cruz. 2001:96:751-5.

28. Stuyver L, De Gendt S, Van Geyt C, Zoulim F, Fried M, Schinazi RF, Rossau $\mathrm{R}$. A new genotype of hepatitis B virus: complete genome and phylogenetic relatedness. J Gen Virol. 2000;81:67-74.

29. Sumi H, Yokosuka O, Seki N, Arai M, Imazeki F, Kurihara T, Kanda T, Fukai K, Kato M, Saisho H. Influence of hepatitis B virus genotypes on the progression of chronic type B liver disease. Hepatology. 2003;37:19-26.

30. Sunbul M, Leblebicioglu H. Distribution of hepatitis B virus genotypes in patient with chronic hepatitis B in Turkey. World J Gastroenterol. 2005;11:1976-80.

31. Telenta PF, Poggio GP, Lopez JL, Gonzalez J, Lemberg A, Campos RH. Increased prevalence of genotype F hepatitis B virus isolates in Buenos Aires, Argentina. J Clin Microbiol. 1997;35:1873-5.

32. Teles SA, Martins RM, Vanderborght B, Stuyver L, Gaspar AM, Yoshida CF. Hepatitis B virus: genotypes and subtypes in Brazilian hemodialysis patients Artif Organs. 1999;23:1074-8.

33. Zollner B, Petersen J, Puchhammer-Stock1 E, Kletzmayr J, Sterneck M, Fischer L, Schröter M, Laufs R, Feucht HH. Viral features of lamivudine resistant hepatitis B genotypes A and D. Hepatology. 2004;39:42-50.

Received 3/4/2009. Accepted 23/6/2009. 